\title{
Estimation of calcium and magnesium in serum and urine by atomic absorption spectrophotometry
}

\author{
CHRISTIAN G. THIN AND PATRICIA A. THOMSON \\ From the Metabolic Unit, Western General Hospital, Edinburgh
}

SYNOPSIS A method has been described for the estimation of calcium and magnesium in serum and urine using atomic absorption spectrophotometry. The precision and accuracy of the techniques have been determined and were found to be acceptable.

The range of values for calcium and magnesium in the sera of normal adults was found to be: serum calcium (corrected to a specific gravity of 1.026) 8.38-10.08 mg. per $100 \mathrm{ml}$.; serum magnesium $1 \cdot 83-2.43 \mathrm{mg}$. per $100 \mathrm{ml}$.

A wide variety of methods has been used for the estimation of calcium and magnesium in biological fluids. Among the more recent, the technique employing the principle of atomic absorption spectroscopy appears to offer a relatively specific method, and one in which interference from other factors can be reduced to a minimum.

The apparatus employed in this laboratory is a Techtron atomic absorption spectrophotometer model A.A.3, manufactured by Techtron Pty. Ltd., Melbourne, Australia ${ }^{1}$. The instrument was used according to the maker's instruction manual.

The reliability of the instrument in estimating calcium and magnesium in serum and urine has been assessed. The precision and accuracy of this method was determined as described by Brown, Bulbrook, and Greenwood (1957).

\section{MATERIALS AND METHODS}

Typical instrument settings are shown in Table I. All solutions for atomization were prepared with glassdistilled or de-ionized water; all estimations were done in duplicate.

CALCIUM Calcium was estimated in serum and urine, using a modification of the method of Willis $(1960,1961)$.

For the estimation in serum, $0.2 \mathrm{ml}$. serum was diluted to $2.5 \mathrm{ml}$. in a solution containing $2,500 \mathrm{mg}$. strontium $\left(7.7 \mathrm{~g}\right.$. strontium chloride $\left.\mathrm{SrCl}_{2} \cdot 6 \mathrm{H}_{2} \mathbf{0}\right)$ per litre and $40 \mathrm{~g}$. trichloracetic acid per litre, in a centrifuge tube. After standing for 10 minutes the tube was centrifuged and the supernatant aspirated directly, without further manipulation. Standard solutions containing $6,8,10,12$, and $14 \mathrm{mg}$. calcium per $100 \mathrm{ml}$., prepared from calcium carbonate Specpure ${ }^{2}$, were similarly diluted.

${ }^{1}$ British Agents-V. A. Howe and Co. Ltd.

Received for publication 28 September 1966.
TABLE I

TYPICAL INSTRUMENT SETTINGS FOR ESTIMATION OF CALCIUM AND MAGNESIUM

Calcium Magnesium

\begin{tabular}{|c|c|c|c|}
\hline Lamp & $\begin{array}{l}\text { Warm-up current (mA) } \\
\text { Regulated current (mA) }\end{array}$ & $\begin{array}{l}15 \\
10\end{array}$ & $\begin{array}{r}10 \\
6\end{array}$ \\
\hline Monochromator & $\begin{array}{l}\text { Slit width (microns) } \\
\text { Wavelength }(\AA)\end{array}$ & $\begin{array}{r}40 \\
4227\end{array}$ & $\begin{array}{r}60 \\
2852\end{array}$ \\
\hline \multirow[t]{2}{*}{ Gas pressure } & $\begin{array}{c}\text { Acetylene (settings on } \\
\text { flow scale) }\end{array}$ & 5 & 4 \\
\hline & Air (lb./in..$\left.^{2}\right)$ & 20 & 20 \\
\hline \multicolumn{2}{|c|}{$\begin{array}{l}\text { Flame characteristics obtained by } \\
\text { adjusting acetylene flow }\end{array}$} & $\begin{array}{l}\text { Slightly } \\
\text { luminous } \\
\text { with } \\
\text { ragged } \\
\text { inner core }\end{array}$ & $\begin{array}{l}\text { Blue, with } \\
\text { clear blue } \\
\text { inner core }\end{array}$ \\
\hline
\end{tabular}

Urine was diluted 1 in 50 in a solution containing $10,000 \mathrm{mg}$. strontium per litre $(30 \cdot 8 \mathrm{~g}$. strontium chloride $\left.\mathrm{SrCl}_{2} \cdot 6 \mathrm{H}_{2} 0\right)$. At the same time, eight standards were prepared, containing 1 to $8 \mathrm{mg}$. calcium per litre in a solution containing $10,000 \mathrm{mg}$. strontium per litre and a blank solution containing $10,000 \mathrm{mg}$. strontium per litre only.

MAGNESIUM Magnesium was estimated by the method of Dawson and Heaton (1961), with a slight modification. N

Serum $(0.2 \mathrm{ml})$ was diluted to $10 \mathrm{ml}$. in $0.1 \mathrm{~N}$ hydrochloric acid. Standards were similarly prepared from solutions containing $1 \cdot 5,2 \cdot 0,2 \cdot 5$, and $3.0 \mathrm{mg}$. magnesium per $100 \mathrm{ml}$. (magnesium crystals spectrographically standardized $\left.{ }^{2}\right)$.

Urine was diluted 1 in 100 in $0.1 \mathrm{~N}$ hydrochloric acid. Eight standards containing from 0.1 to $0.8 \mathrm{mg}$. magnesium per litre in $0.1 \mathrm{~N}$ hyrochloric acid and a blank solution containing $0.1 \mathrm{~N}$ hydrochloric acid were also prepared.

${ }^{2} \mathrm{Obtainable}$ from Johnson, Matthey and Co. Ltd. 
RESULTS AND DISCUSSION

PRECISION OF THE METHOD The precision of the techniques was obtained by the method of Snedecor (1952) in which an estimate (s) of the standard deviation is calculated from the difference between the two results of duplicate determinations in a series of assays.

$$
\text { Estimate of S.D. }=s=\sqrt{\frac{\overline{\Sigma \mathrm{d}^{2}}}{2 \mathrm{~N}}}
$$

$\mathrm{d}=$ difference between duplicate estimations

$\mathrm{N}=$ number of duplicates.

The values of $s$ obtained are shown in Table II.

TA BLE II

ESTIMATES OF PRECISION EXPRESSED AS THE ESTIMATES OF (S) OF RESULTS OF DUPLICATE DETERMINATIONS

\begin{tabular}{lccc} 
& $\begin{array}{c}\text { Number of } \\
\text { Duplicates }\end{array}$ & $\begin{array}{l}\text { Range Covered } \\
(\mathrm{mg} . / 100 \mathrm{ml} .)\end{array}$ & $s$ \\
\hline Serum calcium & 61 & $8.00-11.90$ & 0.12 \\
Serum magnesium & 46 & $1.86-2.70$ & 0.02 \\
Urinary calcium & 68 & $4.20-38.50$ & 0.29 \\
Urinary magnesium & 53 & $3.00-17.30$ & 0.09 \\
\multicolumn{2}{c}{$\mathrm{s}^{2}= \pm \frac{\text { (difference between duplicate determinations) }}{2}$} & \multicolumn{2}{c}{$2 \times$ number of duplicates }
\end{tabular}

The precision of a technique can also be assessed by calculating the standard deviation of a number of analyses performed on one sample. Using this method, Willis (1960) found a mean and standard deviation of $10.04 \pm 0.10 \mathrm{mg}$. calcium per $100 \mathrm{ml}$. in serum and $7.11 \pm 0.08 \mathrm{mg}$. calcium per $100 \mathrm{ml}$. in urine (Willis, 1961). Sunderman Jr. and Carroll (1965), using a Jarrell-Ash spectrophotometer, obtained standard deviations of \pm 0.11 and \pm 0.03 for calcium and magnesium, respectively, in serum.

The method described in this paper yields results that compare favourably with those of other workers.

ACCURACY OF THE METHOD The accuracy of the method was estimated by recovery experiments. Known amounts of calcium or magnesium were added to serum and urine at the time of dilution, before analysis, and the results compared with those from a similar sample (the endogenous control) not containing the added calcium or magnesium. The results obtained are shown in Table III.

These results compare favourably with those obtained by other workers. Willis (1961) recovered from urine $99.1 \%$ of added calcium and $100.7 \%$ of added magnesium. Sunderman Jr. and Carroll (1965) added to serum $4 \mathrm{mg}$. calcium per $100 \mathrm{ml}$. and $0.8 \mathrm{mg}$. magnesium per $100 \mathrm{ml}$. and recovered $100 \pm 3 \cdot 3 \%$ and $102 \pm 4 \cdot 3 \%$, respectively.
TABLE III

RECOVERY OF CALCIUM AND MAGNESIUM FROM SERUM AND URINE ${ }^{1}$

\begin{tabular}{|c|c|c|c|c|}
\hline & & $\begin{array}{l}\text { Amount Added } \\
(\mathrm{mg} / 100 \mathrm{ml} .)\end{array}$ & $\begin{array}{l}\text { Number of } \\
\text { Determinations }\end{array}$ & Recovery \\
\hline \multicolumn{5}{|l|}{ Calcium } \\
\hline & Serum & 10 & 45 & $99 \cdot 0 \pm 2 \cdot 2$ \\
\hline & & 12 & 21 & $98.0 \pm 1.9$ \\
\hline & Urine & 5 & 29 & $101.0 \pm 4.0$ \\
\hline & & 10 & 24 & $99.8 \pm 2.8$ \\
\hline \multicolumn{5}{|c|}{ Magnesium } \\
\hline & Serum & 2 & 19 & $99.8 \pm 3.3$ \\
\hline & & $2 \cdot 5$ & 19 & $100 \cdot 2 \pm 2 \cdot 2$ \\
\hline & Urine & 2 & 27 & $99.5 \pm 3.5$ \\
\hline & & 4 & 28 & $99.0 \pm 2.1$ \\
\hline
\end{tabular}

${ }^{1}$ Results are shown as the mean percentage recovery \pm the coefficient of variation and are corrected for the endogenous blank values.

SERUM CALCIUM AND MAGNESIUM LEVELS IN NORMAL SUBJECTS Samples of serum were obtained from 138 normal adults, 85 male and 52 female, aged between 18 and 63 years, who were attending blood transfusion service clinics as donors. The concentrations of calcium and magnesium were determined as previously described. The specific gravity of the samples was determined by the copper sulphate method (Phillips, Van Slyke, Hamilton, Dole, Emerson Jr., and Archibald, 1950).

Dent (1962) recommended that all results of plasma calcium estimations be corrected to a specific gravity of 1.027 . In this study all estimations, including specific gravity, were performed on serum. The mean value obtained for serum specific gravity was 1.026 . We have compared the specific gravity of 85 samples of serum and plasma obtained from patients at a single venipuncture. The mean value obtained for the specific gravity of serum was 1.02533 (range 1.022-1.028 S.D. \pm 0.0019 ) and the mean for the specific gravity of plasma was 1.02659 (range 1.023-1.030 S.D. \pm 0.0021 ). The difference of 0.00126 was highly significant $(P<0.001)$.

As several of the samples of plasma were slightly haemolysed, we compared 38 pairs of serum and plasma specimens, where both the serum and the plasma were known to be free of haemolysis. The mean value obtained for the specific gravity of the serum was 1.02587 (range 1.022-1.027, S.D. \pm 0.0019 ) and the mean for the specific gravity of the plasma 1.02685 (range 1.024-1.028, S.D. \pm 0.0014 ). The difference between the means of 0.00098 was highly significant $(P<0.001)$. As a result of this investigation, we now correct all estimations of calcium in serum to a specific gravity of $\mathbf{1 . 0 2 6}$.

The range of values of serum calcium and magnesium found in this series of normal adults is shown in Table IV, together with the calculated ranges within $95 \%$ confidence limits. As the concentrations 
TABLE IV

THE DISTRIBUTION, ACTUAL RANGE, AND CALCULATED RANGB (WITHIN 95\% CONFIDENCE LIMTTS) OF SERUM CALCIUM AND MAGNESIUM CONCENTRATIONS ${ }^{1}$

\begin{tabular}{|c|c|c|c|c|c|}
\hline & $\begin{array}{l}\text { Number of } \\
\text { Samples }\end{array}$ & Actual Range & Median & Mean & $\begin{array}{l}\text { Calculated } \\
\text { Range } \\
(P<0.05)\end{array}$ \\
\hline $\begin{array}{l}\text { Calcium } \\
\text { Uncorrected }\end{array}$ & 137 & $8 \cdot 00-10 \cdot 25$ & $9 \cdot 13$ & $9 \cdot 21$ & $8.37-10.05$ \\
\hline $\begin{array}{l}\text { Corrected to } \\
\text { specific } \\
\text { gravity of } \\
1026\end{array}$ & 137 & $8 \cdot 15-10 \cdot 25$ & $9 \cdot 20$ & $9 \cdot 23$ & $8 \cdot 38-10 \cdot 08$ \\
\hline Magnesium & 138 & $1 \cdot 70-2.65$ & $2 \cdot 18$ & $2 \cdot 13$ & $1.83-2.43$ \\
\hline
\end{tabular}

${ }^{1}$ Results are expressed in $\mathrm{mg} / 100 \mathrm{ml}$.

\section{TABLE V}

THE DISTRIBUTION OF SERUM CALCIUM AND MAGNESIUM CONCENTRATIONS WITH RESPECT TO SEX AND AGE ${ }^{1}$

\begin{tabular}{lllll} 
Sex & $\begin{array}{l}\text { Age } \\
\text { (years) }\end{array}$ & Number & $\begin{array}{l}\text { Calcium } \\
\text { Range } \\
\text { (Mean value } \\
\pm 2 \times S . D .)\end{array}$ & $\begin{array}{l}\text { Magnesium } \\
\text { Range } \\
(\text { Mean value } \\
\pm 2 \times S . D .)\end{array}$ \\
\hline \multirow{4}{*}{ Male } & $18-62$ & 85 & $9 \cdot 26 \pm 0.88$ & $2 \cdot 16 \pm 0.15$ \\
& $18-40$ & 46 & $9 \cdot 11 \pm 0.96$ & $2 \cdot 14 \pm 0.14$ \\
& $40-62$ & 22 & $9 \cdot 20 \pm 0.92$ & $2.18 \pm 0.13$ \\
Female & $18-63$ & 52 & $9 \cdot 18 \pm 0.82$ & $2.09 \pm 0.15$ \\
& $18-40$ & 26 & $9 \cdot 27 \pm 0.86$ & $2.05 \pm 0.13$ \\
& $40-63$ & 18 & $9 \cdot 13 \pm 0.74$ & $2.09 \pm 0.18$
\end{tabular}

${ }^{1}$ Results are expressed in $\mathrm{mg}$./100 $\mathrm{ml}$. of some serum constituents are affected by sex and age, the results were analysed further in Table $\mathrm{V}$. The calculated ranges were compared statistically by the $t$ test. There was found to be no significant difference between the sexes, or between the age groups at the $\mathbf{P}=0.05$ level.

The authors wish to thank Professor J. A. Strong for his constant encouragement. We also thank Dr. R. A. Cumming, of the Blood Transfusion Service, for his cooperation and Mr.J. H. Filshie, of the Poultry Research Unit, and V. A. Howe and Co. Ltd, for their help and advice in setting up the Techtron atomic absorption spectrophotometer.

\section{REFERENCES}

Brown, J. B., Bulbrook, R. D., and Greenwood, F. C. (1957). J. Endocr., 16, 41.

Dawson, J. B., and Heaton, F. W. (1961). Biochem. J., 80, 99.

Dent, C. E. (1962). Brit. med. J., 2, 1419.

Phillips, R. A., Van Slyke, D. D., Hamilton, P. B., Dole, V. P., Emerson, K., Jr., and Archibald, R. M. (1950). J. biol. Chem., 183, 305.

Snedecor, G. W. (1952). Biometrics, 8, 85.

Sunderman, F. W., Jr., and Carroll, J. E. (1965). Amer. J. clin. Path., $43,302$.

Willis, J. B. (1960). Spectrochim. Acta, 16, 259.

(1961). Anal. Chem., 33, 556. 